\title{
Amino acid supplementation of calf milk replacers containing plasma protein
}

\author{
S. Y. Morrison, ${ }^{*}$ J. M. Campbell, † and J. K. Drackley*1 \\ *Department of Animal Sciences, University of Illinois, Urbana 61801 \\ †APC Inc., 2425 SE Oak Tree Court, Ankeny, IA 50021
}

\section{ABSTRACT}

We determined the effects of calf milk replacers containing 0,5 , or $10 \%$ bovine plasma protein $(\mathrm{PP})$, either without or with the supplemental amino acids (AA) Ile and Thr, on growth and health of male Holstein calves $(\mathrm{n}=104)$ for $56 \mathrm{~d}$. Milk replacers were formulated to contain $22 \%$ crude protein (CP), $20 \%$ fat, and $2.0 \%$ Lys. Milk replacers (12.5\% solids) were fed at a rate of $1.5 \%$ of body weight $(\mathrm{BW})$ on a dry matter basis during wk 1 and $1.75 \%$ of BW beginning on $\mathrm{d} 8$. Starter was introduced on d 36 so that effects of PP and AA balance in milk replacers could be isolated. Intake, respiratory scores, and fecal scores were measured daily. Body weight and stature were measured weekly and blood serum samples were obtained during wk 4. Treatments had no effects on intakes of dry matter, CP, or metabolizable energy. During wk 6 and 8 , $\mathrm{BW}$ was less as PP inclusion increased without AA supplementation compared with the other treatments. In wk 7, calves fed the higher level of PP without AA had lower BW than calves fed either the lower level of PP without supplemented AA or the higher inclusion of PP with supplemented AA. Average daily gain and gain:feed were lowest for calves fed the higher inclusion of $\mathrm{PP}$ without supplemented AA; heart girth in wk 7 was smallest for those calves. During the first 21 $\mathrm{d}$, occurrence of scours was greater in calves fed the control milk replacer than in calves fed milk replacers containing the higher inclusion of PP either without or with supplemental AA. Occurrence of scours was also greater for the lower inclusion of PP compared with the higher inclusion of PP when AA were supplemented. Throughout the 56-d experiment, the chance of antibiotic treatment was greater for calves fed the control milk replacer than for all other treatments except the higher inclusion of PP without supplemental AA. Additionally, chance of antibiotic treatment was greater for the higher inclusion of PP without supplemental AA than for other milk replacers with PP. Calves fed treat-

Received December 5, 2016

Accepted January 21, 2017.

${ }^{1}$ Corresponding author: drackley@illinois.edu ments with the higher inclusion of PP had fewer days of scours than the controls. All milk replacers with PP, except the milk replacer containing higher PP without supplemental AA, had fewer days of treatment with antibiotics compared to the all-milk control. Inclusion of PP provided similar performance and improved health as long as milk replacers were balanced for Ile and Thr. Key words: calf, milk replacer, plasma protein, essential amino acids

\section{INTRODUCTION}

In the United States, over $85 \%$ of heifers are fed milk replacer (MR) for at least a portion of the preweaning period (NAHMS, 2011). Conventional (limit-fed) MR typically contain 20 to $22 \% \mathrm{CP}$ and $20 \%$ fat (dry basis) and are traditionally formulated using milk protein sources (now principally whey proteins) because of their high digestibility and desirable AA profile for preweaned calves (Davis and Drackley, 1998). In MR formulation, however, protein ingredients are a major portion of the cost. With increasing demand from the human market, milk-derived proteins such as whey protein concentrate can become increasingly more expensive. Identification of non-milk protein sources that provide similar growth and health but at lower cost continues to be an important research objective.

Spray-dried plasma proteins (PP) are highly digestible and have a favorable EAA profile, with the exception of Met and Ile (Almeida et al., 2013). In addition, PP are processed to maintain the functional characteristics of proteins such as albumin and IgG. Plasma proteins have been evaluated in calf $\mathrm{MR}$ and have resulted in similar (Quigley and Bernard, 1996; Quigley and Wolfe, 2003) or improved (Morrill et al., 1995; Quigley et al., 2002) performance compared with all-milk protein MR. In those studies, PP replaced up to $25 \%$ of total CP from milk sources. In a study by Vasquez et al. (2017), the inclusion of $\mathrm{PP}$ was evaluated over a wide range of whey protein replacement in calf MR, and results indicated that replacing up to $33 \%$ of the total dietary $\mathrm{CP}$ with $\mathrm{PP}$ did not reduce performance.

Research in pigs has demonstrated that maximum PP inclusion is likely dependent on Ile content of the 
diet because Ile is the most limiting AA after Met (Torrallardona, 2010). Results from the study conducted by Vasquez et al. (2017) indicated that Thr might become limiting for growth in young calves as PP inclusion increases, even with Ile addition. Evaluation of AA supplementation with inclusion of PP may aid in the understanding and formulation of more cost-effective calf MR that perform similarly to conventional MR.

Our objective in this experiment was to determine the effects of calf MR containing 0,18 , or $36 \%$ of total replaceable milk protein as bovine $\mathrm{PP}$, either without or with supplemental Ile and Thr, on calf growth and health.

\section{MATERIALS AND METHODS}

\section{Calves, Arrival, and Processing}

All procedures were conducted under protocols approved by the University of Illinois Institutional Animal Care and Use Committee (protocol 13138). The study was conducted from October 2013 to February 2014. A total of 105 male Holstein calves, less than 1 wk old, were selected at a local farm in east-central Illinois. Three groups of calves were brought to the research site at different times throughout the course of the study due to calf availability and space limitations at the research facility. The groups included 40 calves in the first group, 20 calves in the second group, and 45 calves in the third group. At the time of selection, blood samples were taken from the jugular vein into $10-\mathrm{mL}$ evacuated serum separation tubes (Becton Dickinson, Rutherford, NJ). Blood was centrifuged at $1,300 \times g$ for $15 \mathrm{~min}$, and a refractometer was used to determine total protein concentration in the serum for all potential calves. Calves were selected based on total protein in serum and visual health assessment. After selection, calves were transported to the research site. All calves selected were given $2 \mathrm{~mL}$ of BO-SE (Merck Animal Health, Kenilworth, NJ), $1 \mathrm{~mL}$ of vitamins A and D (Sparhawk Laboratories Inc., Lenexa, KS), and $2 \mathrm{~mL}$ of Inforce (Pfizer, New York, NY). If a calf was chosen for the trial and had a total protein of $<5.5$ $\mathrm{g} / \mathrm{dL}$, it was also given $50 \mathrm{~mL}$ of Bovisera (Colorado Serum Co., Denver, CO) and $20 \mathrm{~mL}$ of clostridial C and D antitoxin (Boehringer Ingelheim, Ridgefield, CT). Initial measurements of BW, body length, heart girth, withers height, hip height, and hip width were obtained after arrival at the research facility. In each group of calves, all treatments were equally represented within blocks, and once all calves were enrolled, each treatment group had 21 calves.

\section{Housing}

Calves were housed in south-facing individual hutches (Calf-tel, Hampel Corp., Germantown, WI) placed approximately $1.5 \mathrm{~m}$ apart. Hutches were placed on a base of crushed rock, which was covered by landscape cloth and a layer of straw. Straw was checked daily and more added as needed. Temperature and humidity were recorded using data from the local weather station.

\section{Experimental Diets}

Calves were blocked on the day of arrival (d 0) by BW and serum total protein concentration and then randomly assigned within block to 1 of $5 \mathrm{MR}$ treatments that contained increasing amounts of PP (NutraPro B, APC Inc., Ankeny, IA) without or with supplemental Ile and Thr. All treatments resembled a commercial formula containing $22 \% \mathrm{CP}$ and $20 \%$ fat and were formulated to contain $2.0 \%$ Lys (Table 1 ).

The treatments were control, an all-milk protein MR with Met added to achieve a Met:Lys ratio of $0.31(\mathbf{M})$; $5 \%$ addition of PP (18\% of CP) with Met added to equal the ratio in treatment $\mathrm{M}(\mathbf{5 P}) ; 5 \% \mathrm{PP}$ addition as in treatment $5 \mathrm{P}$ but with Ile and Thr added to equal the amounts in treatment M (5PA); $10 \%$ addition of PP (36\% of CP) with Met added to equal the ratio in treatment $\mathrm{M}(\mathbf{1 0 P})$; and $10 \% \mathrm{PP}$ addition as in treatment 10P but with Ile and Thr added to equal amounts in treatment M (10PA). Milk replacers were manufactured by Milk Specialties Global Animal Nutrition (Eden Prairie, MN).

\section{Feeding and Management}

Calves were fed twice daily at 0500 and $1630 \mathrm{~h}$. All MR were reconstituted to $12.5 \%$ solids. For the first $2 \mathrm{~d}$ after arrival MR were fed at a rate of $1.25 \%$ (DM basis) of arrival BW. For the remainder of the first week (d 3-7) calves were fed MR at a rate of $1.5 \%$ of arrival BW. Beginning on d $8 \mathrm{MR}$ was fed at a rate of $1.75 \%$ of BW, adjusted weekly. Milk replacer intake was recorded daily. During wk 8 (d 50-56) calves were fed MR only one time per day, and after d 56 MR was no longer fed. Water was offered for ad libitum consumption, and intake was recorded daily. Calf starter (AMPLI-CALF Starter 22, Purina Animal Nutrition LLC, Gray Summit, MO) was fed beginning in wk 6 (d 36) for ad libitum intake and intake was measured daily. No starter was offered during the first $5 \mathrm{wk}$ so that potential differences in MR protein source and AA balance could be detected with greater sensitivity. 


\section{Health}

Health checks were performed daily. Fecal scores were assigned on a 1 to 4 scale: $1=$ normal and well formed; $2=$ soft but still holds form; 3 = loose without form; and $4=$ consistency of water. Respiratory scores were assigned on a 1 to 5 scale: $1=$ normal; $2=$ open mouth breathing; $3=$ open mouth breathing with mucus; 4 $=$ dry cough; and $5=$ wet cough. Overall appearance and behavior also were recorded. After arrival rectal temperature was measured daily for $5 \mathrm{~d}$ and at any time that a calf showed signs of illness throughout the duration of the study. Flunexin meglumine (Phoenix Pharmaceutical Inc., St. Joseph, MO) was administered to calves with a rectal temperature of $40^{\circ} \mathrm{C}$ or above. Navels were dipped in povidone iodine as needed until dry. Animals were monitored multiple times daily for illness and dehydration status and treated as needed. Hydration status was assessed using fecal scores, skin tent test, eye appearance, and overall attitude. An

Table 1. Ingredient and formulated chemical composition of milk replacers containing plasma protein (PP) without or with supplemental Ile and Thr

\begin{tabular}{|c|c|c|c|c|c|}
\hline \multirow[b]{2}{*}{ Component } & \multicolumn{5}{|c|}{ Treatment $^{1}$} \\
\hline & M & $5 \mathrm{P}$ & $5 \mathrm{PA}$ & $10 \mathrm{P}$ & $10 \mathrm{PA}$ \\
\hline \multicolumn{6}{|l|}{ Ingredient, \% DM } \\
\hline Whey, $10.5 \%$ CP & 23.98 & 23.61 & 23.57 & 24.38 & 24.91 \\
\hline Delactosed whey, $24 \% \mathrm{CP}$ & 20.00 & 20.00 & 20.00 & 20.00 & 20.00 \\
\hline $\mathrm{WPC},{ }^{2} 34 \% \mathrm{CP}$ & 10.00 & 10.00 & 10.00 & 8.22 & 7.26 \\
\hline WPC, $76.2 \%$ CP & 10.10 & 4.72 & 4.54 & - & - \\
\hline 7/60 MR (fat) & 10.00 & 10.00 & 10.00 & 10.00 & 10.00 \\
\hline 12/50 MR (fat) & 23.69 & 24.30 & 24.32 & 24.90 & 24.94 \\
\hline Dicalcium phosphate & 0.33 & 0.17 & 0.18 & - & 0.0039 \\
\hline Vitamin E premix & 0.13 & 0.13 & 0.13 & 0.13 & 0.13 \\
\hline Mineral premix ${ }^{3}$ & 1.56 & 1.56 & 1.56 & 1.56 & 1.56 \\
\hline DL-Met & 0.21 & 0.26 & 0.26 & 0.31 & 0.31 \\
\hline 98\% Trp & 0.0124 & 0.0049 & 0.0071 & - & 0.0056 \\
\hline Limestone & - & 0.16 & 0.16 & 0.34 & 0.34 \\
\hline Spray dried bovine plasma ${ }^{4}$ & - & 5.00 & 5.00 & 10.00 & 10.00 \\
\hline L-Lys (HCl), $95 \%$ & - & 0.09 & 0.11 & 0.18 & 0.21 \\
\hline L-Thr & - & - & 0.05 & - & 0.10 \\
\hline L-Ile & - & - & 0.12 & - & 0.23 \\
\hline \multicolumn{6}{|l|}{ Nutrient } \\
\hline $\mathrm{CP}, \%$ & 22.00 & 22.00 & 22.00 & 22.00 & 22.00 \\
\hline Crude fat, \% & 20.00 & 20.00 & 20.00 & 20.00 & 20.00 \\
\hline Crude fiber, $\%$ & - & 0.02 & 0.02 & 0.03 & 0.03 \\
\hline $\mathrm{GE}, \mathrm{kcal} / \mathrm{kg}$ & 4,746 & 4,733 & 4,732 & 4,716 & 4,712 \\
\hline Lactose, $\%$ & 40.87 & 40.55 & 40.52 & 40.13 & 40.02 \\
\hline $\mathrm{Ca}, \%$ & 1.12 & 1.12 & 1.12 & 1.12 & 1.12 \\
\hline $\mathrm{P}, \%$ & 0.82 & 0.82 & 0.82 & 0.82 & 0.82 \\
\hline Vitamin A, kIU/kg & 66.18 & 66.11 & 66.11 & 66.04 & 66.04 \\
\hline Vitamin $\mathrm{D}, \mathrm{kIU} / \mathrm{kg}$ & 23.08 & 23.08 & 23.08 & 23.08 & 23.08 \\
\hline Vitamin E, IU/kg & 330.04 & 330.04 & 330.04 & 330.04 & 330.04 \\
\hline Lys, \% & 2.04 & 2.04 & 2.04 & 2.04 & 2.04 \\
\hline Met, $\%$ & 0.63 & 0.63 & 0.63 & 0.63 & 0.63 \\
\hline Ile, $\%$ & 1.33 & 1.23 & 1.33 & 1.12 & 1.33 \\
\hline Thr, $\%$ & 1.55 & 1.51 & 1.55 & 1.46 & 1.55 \\
\hline His, $\%$ & 0.38 & 0.46 & 0.46 & 0.54 & 0.53 \\
\hline Leu, \% & 2.30 & 2.27 & 2.25 & 2.23 & 2.21 \\
\hline Val, \% & 1.27 & 1.30 & 1.29 & 1.33 & 1.31 \\
\hline Phe, \% & 0.73 & 0.83 & 0.83 & 0.93 & 0.92 \\
\hline $\operatorname{Trp}, \%$ & 0.35 & 0.35 & 0.35 & 0.35 & 0.35 \\
\hline Arg, $\%$ & 0.57 & 0.70 & 0.69 & 0.83 & 0.82 \\
\hline Cys, \% & 0.50 & 0.50 & 0.50 & 0.50 & 0.50 \\
\hline Tyr, \% & 0.61 & 0.67 & 0.66 & 0.73 & 0.73 \\
\hline
\end{tabular}


electrolyte solution (Land O'Lakes Electrolyte System, Land O'Lakes Inc., Arden Hills, MN) was administered as needed. Calves were administered vaccinations following standard procedures of the facility. Calves were not castrated until after completion of the study.

\section{Feed Analysis}

Milk replacers were sampled once weekly and stored at $-20^{\circ} \mathrm{C}$ until analysis. Composite samples were prepared for each batch of calves and were analyzed by Dairy One (Ithaca, NY) for DM, CP, fat, ash, Ca, P, $\mathrm{Mg}, \mathrm{K}, \mathrm{Na}, \mathrm{Fe}, \mathrm{Zn}, \mathrm{Cu}, \mathrm{Mn}, \mathrm{Mo}$, and $\mathrm{S}$ by standard wet chemistry methods (www.dairyone.com). Values for ME were estimated from chemical composition as described (www.dairyone.com). Composite samples were also sent to the University of Missouri Agricultural Experiment Station Laboratory (Columbia, MO) for complete AA analysis by cation-exchange chromatography coupled with post-column ninhydrin derivatization and quantification. The laboratory used base-catalyzed hydrolysis so that tryptophan content could be determined.

Starter was sampled weekly when it was being fed and stored at $-20^{\circ} \mathrm{C}$ until analysis. Composite samples were prepared for each batch of calves and analyzed by Dairy One using wet chemistry techniques for DM, CP, lignin, fat, ash, starch, ME, Ca, P, Mg, K, Na, Fe, Zn, $\mathrm{Cu}, \mathrm{Mn}, \mathrm{Mo}, \mathrm{S}$, and $\mathrm{Cl}$.

\section{Body Growth and Measurements}

Body weight, body length, heart girth, withers height, hip height, and hip width were measured upon arrival and weekly thereafter for the duration of the trial. Body weight and growth measures were obtained at $1200 \mathrm{~h}$ on the day specified for each group of calves based on their arrival date.

\section{Blood Collection and Analysis}

Blood was sampled at the end of wk 4 before the morning feeding and $4 \mathrm{~h}$ after the morning feeding. Blood was collected via jugular venipuncture into 10$\mathrm{mL}$ evacuated serum separation tubes (Becton Dickinson). Blood was allowed to clot and then centrifuged at $1,300 \times g$ for $20 \mathrm{~min}$. Serum was divided into aliquots in polypropylene tubes and stored at $-20^{\circ} \mathrm{C}$ until analyzed.

Serum samples were analyzed for concentrations of urea $\mathrm{N}(\mathrm{mg} / \mathrm{dL})$, total protein $(\mathrm{g} / \mathrm{dL})$, and albumin $(\mathrm{g} /$ $\mathrm{dL}$ ) at the University of Illinois College of Veterinary Medicine diagnostic laboratory (Urbana, IL) using automated enzymatic analysis procedures. Total globulin
(g/dL) was calculated as the difference between total protein and albumin.

\section{Statistical Analysis}

The study was conducted as a randomized complete block design. Data were checked for homogeneity of variance and normality assumptions throughout by residual plots and Shapiro-Wilk test using PROC UNIVARIATE in SAS v 9.4 (SAS Inst. Inc., Cary, NC). Because of inherent variability in composition of MR with added AA (Castro et al., 2016; Vasquez et al., 2017), we tested the AA composition among treatments by conducting an ANOVA using the GLM procedure in SAS, with sample considered the experimental unit. The Tukey adjustment was used to determine the differences among treatments.

The ANOVA for growth and intake variables was conducted using the MIXED procedure in SAS. Calf, block, and group were defined as random effects in all models; however, group was nonsignificant and was dropped from the final models. Treatment was defined as a fixed effect. For variables with repeated measurements, a covariate (initial measurement) was used to analyze the data. Calf within block was the subject for repeated measurements. Three covariance structures were evaluated: compound symmetry, autoregressive order 1, and unstructured covariance. The one that minimized the adjusted and unadjusted Akaike information criteria, the Bayesian information criterion, and -2 ratio log-likelihood with the least number of parameters was chosen. Least squares means for treatment effects were separated by use of the PDIFF statement when the overall $F$-test was $P<0.05$.

Models for occurrence of scours and treatment with antibiotics were evaluated by logistic regression using a binomial distribution in the GLIMMIX procedure in SAS. Odds ratio (OR) was used to compare the likelihood of 2 treatments to incur any event. Duration of scouring and administration of medication were evaluated with a Poisson distribution using the GENMOD procedure (SAS Inst. Inc.). Significance was declared at $P<0.05$ and trends discussed when $0.05<P<0.10$. Least squares means were calculated and are presented with standard errors.

\section{RESULTS}

\section{Environment}

Three groups of calves were brought to the research facility at different times and environmental conditions were recorded for each group. For the first group of 
Table 2. Analyzed chemical composition (mean $\pm \mathrm{SD}$ ) of milk replacers containing plasma protein $(\mathrm{PP})$ without or with supplemental Ile and Thr and starter

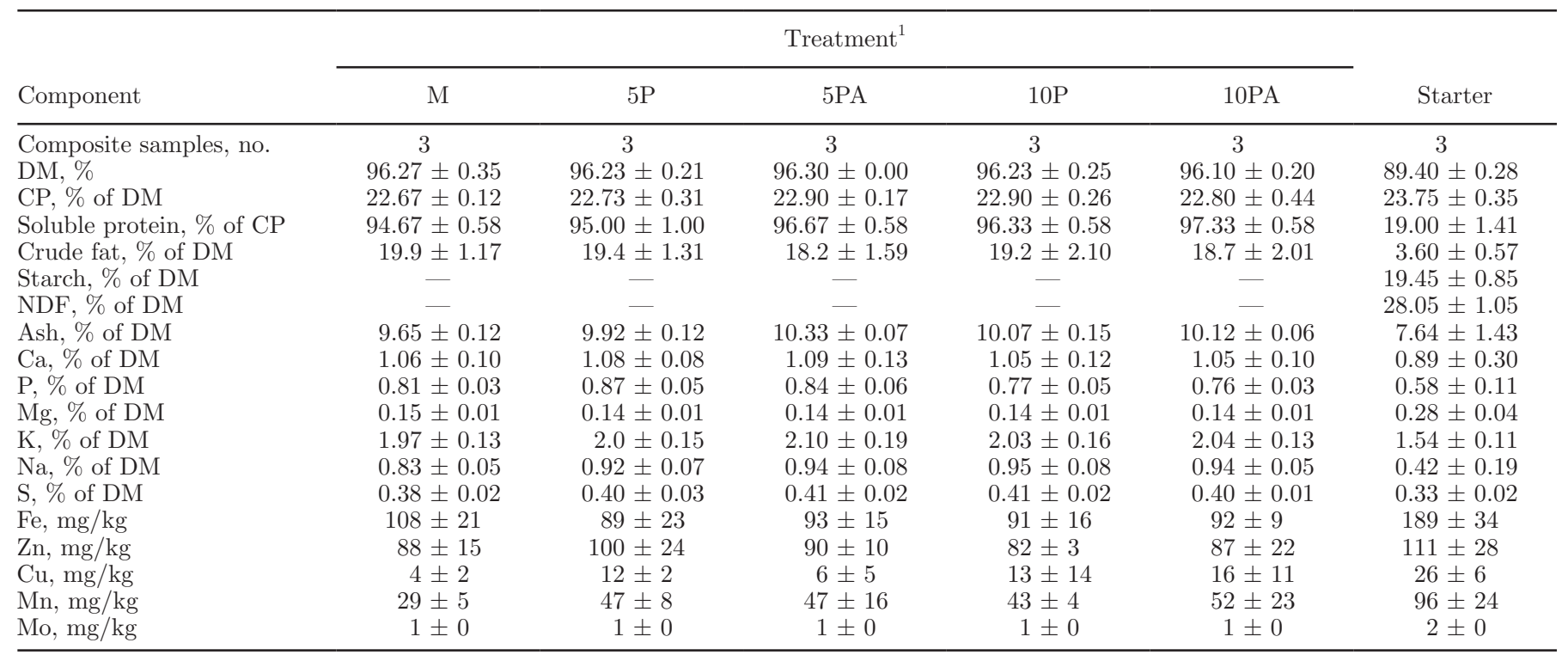

${ }^{1} \mathrm{M}=$ all-milk control; $5 \mathrm{P}=5 \% \mathrm{PP} ; 5 \mathrm{PA}=5 \% \mathrm{PP}$ with Ile and Thr to equal M; $10 \mathrm{P}=10 \% \mathrm{PP} ; 10 \mathrm{PA}=10 \% \mathrm{PP}$ with Ile and Thr to equal M.

calves $(\mathrm{n}=40)$ the daily mean high temperature was $14^{\circ} \mathrm{C}$ and the low temperature was $2^{\circ} \mathrm{C}$. The second group of calves $(\mathrm{n}=20)$ had a daily mean high of $7^{\circ} \mathrm{C}$ and a low of $-3^{\circ} \mathrm{C}$. The third group of calves ( $\mathrm{n}$ $=45$ ) had a daily mean high of $-1^{\circ} \mathrm{C}$ and a low of $-11^{\circ} \mathrm{C}$. The effect of replicate (group) was included in the original models, and interactions of treatment with group were evaluated; however, no significant interactions occurred. Average intake for the first 5 wk when no starter was fed should have been adequate for 560 $\mathrm{g} / \mathrm{d}$ of energy allowable ADG and $530 \mathrm{~g} / \mathrm{d}$ of apparent digestible protein allowable gain under thermoneutral conditions according to NRC (2001).

\section{Nutrient Composition of Diets}

Analyzed chemical composition of $\mathrm{MR}$ is shown in Table 2. The MR were formulated to contain $22 \% \mathrm{CP}$, which was achieved for all treatments. Amino acid analyses of MR on an as-fed basis are shown in Table 3. Analyzed Lys for the control (M) was $1.90 \%$ and ranged from $1.88 \%$ for treatment 5PA to $1.95 \%$ for treatment $5 \mathrm{P}$ and $10 \mathrm{P}$, but these small differences did not differ $(P=0.52)$ among treatments. With this formulation and feeding rate, Lys should have been limiting and calves should have been responsive to differences in protein digestibility or AA balance with equal intake of DM. Additionally, no differences $(P=0.69)$ were present in analyzed Met among treatments. As designed a difference $(P<0.001)$ existed in analyzed Ile among treatments. Treatments $\mathrm{M}$ and 5PA provided the most
Ile $(1.32 \%)$, whereas treatments $5 \mathrm{P}$ and $10 \mathrm{PA}$ provided 1.20 and $1.17 \%$, respectively, and treatment $10 \mathrm{P}$ provided only $1.06 \%$ Ile in the diet. Although treatments 5PA and 10PA were supplemented with Thr, the analyzed concentration did not differ $(P=0.16)$ among treatments.

The AA composition relative to Lys is shown in Table 4. Methionine was formulated at $31 \%$ of Lys (i.e., $0.63 \%$ of dietary DM). Analyzed Met content was $30.1 \%$ for the control, and relative Met contents ranged from 23.3 to $28.3 \%$ for the other treatments, but no difference $(P$ $=0.59$ ) was present among treatments. Analyzed Ile of the control diet was $69.4 \%$ of Lys. Supplementation of Ile in the 5PA diet increased the concentration relative to the respective unsupplemented diet. Treatment 5PA supplied Ile at $69.9 \%$ of Lys, similar to the control diet as desired; however, treatment 10PA did not achieve the same Ile value as the control and provided similar amounts relative to Lys as treatments $5 \mathrm{P}$ and $10 \mathrm{P}$. Analyzed Thr content of the control diet was $78.4 \%$ of Lys. Supplementation of Thr numerically increased the concentration relative to Thr in the unsupplemented MR with PP, but this difference did not achieve significance $(P=0.07)$.

\section{Intakes}

Overall intakes of DM, CP, ME, and Lys from MR for wk 1 to 5 and wk 6 to 8 are shown in Table 5 . During wk 6 to 8 , a tendency $(P=0.08)$ existed for a difference of MR intake, with calves fed treatments $\mathrm{M}$, 
Table 3. Analyzed AA composition (as-fed basis, mean $\pm \mathrm{SD}$ ) of experimental milk replacers containing plasma protein (PP) without or with supplemental Ile and Thr

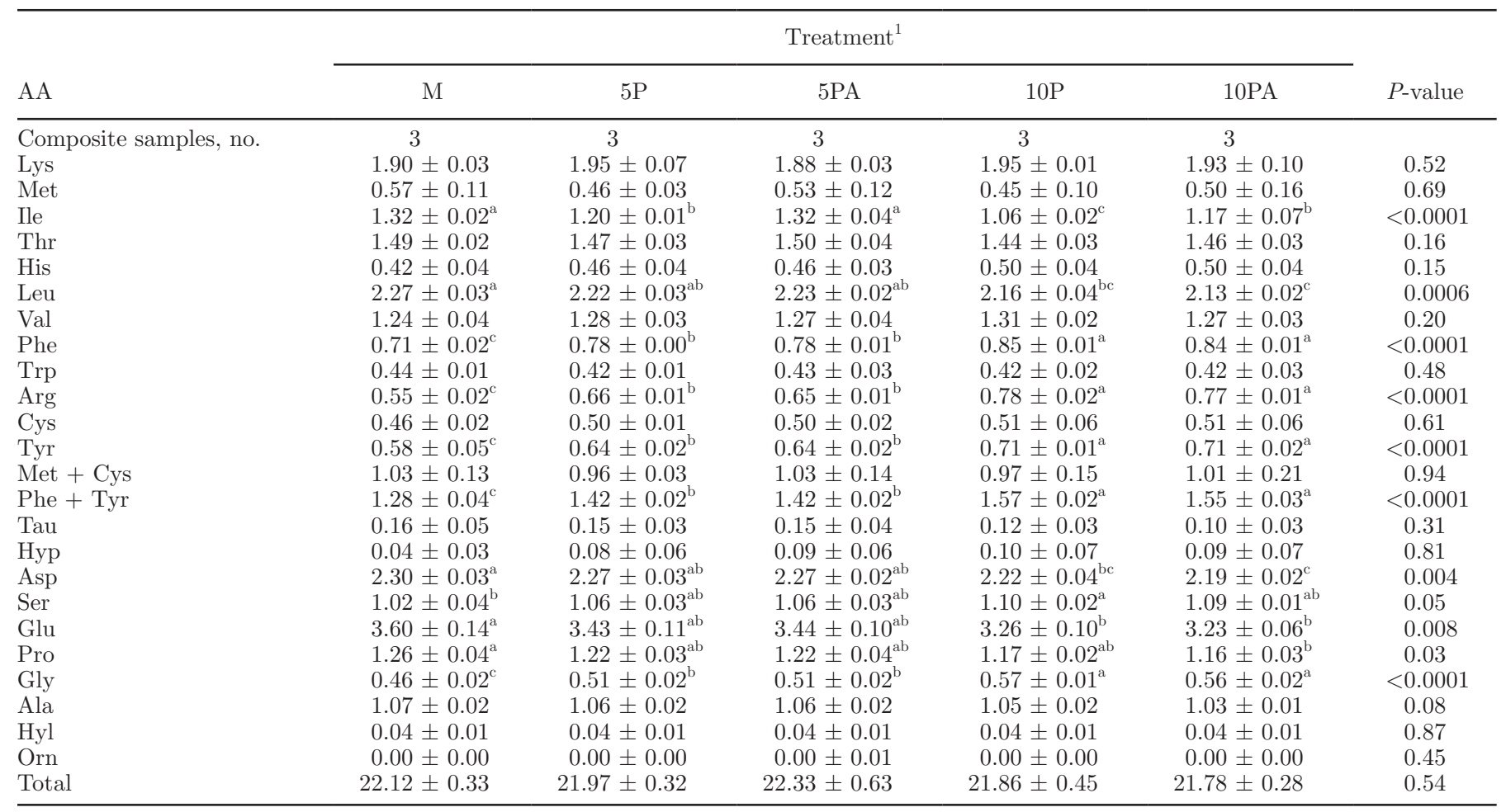

${ }^{\mathrm{a}-\mathrm{c}}$ Means within a row with different superscripts differ $(P<0.05)$.

${ }^{1} \mathrm{M}=$ all-milk control; $5 \mathrm{P}=5 \% \mathrm{PP} ; 5 \mathrm{PA}=5 \% \mathrm{PP}$ with Ile and Thr to equal $\mathrm{M} ; 10 \mathrm{P}=10 \% \mathrm{PP} ; 10 \mathrm{PA}=10 \% \mathrm{PP}$ with Ile and Thr to equal M.

5P, 5PA, and 10PA consuming 897, 912, 906, and 913 $\mathrm{g} / \mathrm{d}$, respectively; calves fed treatment $10 \mathrm{P}$ consumed $863 \mathrm{~g} / \mathrm{d}$. During wk 6 to 8 , a tendency $(P=0.09)$ existed for a difference of ME intake from MR, with calves fed treatments $\mathrm{M}, 5 \mathrm{P}, 5 \mathrm{PA}$, and 10PA consuming 4,054, 4,093, 4,000, and 4,058 kcal/d, respectively; calves fed treatment $10 \mathrm{P}$ consumed $3,863 \mathrm{kcal} / \mathrm{d}$. A significant treatment difference occurred for Lys intake

Table 4. Analyzed AA profiles (\% of Lys) of experimental milk replacers containing plasma protein (PP) without or with supplemental Ile and Thr

\begin{tabular}{lcccccc}
\hline & \multicolumn{7}{c}{ Treatment $^{1}$} \\
\cline { 2 - 5 } AA & $\mathrm{M}$ & $5 \mathrm{P}$ & $5 \mathrm{PA}$ & $10 \mathrm{P}$ & $10 \mathrm{PA}$ & \multirow{2}{*}{$P$-value } \\
\hline Composite samples, no. & 3 & 3 & 3 & 3 & 3 & \\
Lys & 100.0 & 100.0 & 100.0 & 100.0 & 100.0 & - \\
Met & 30.1 & 23.7 & 28.3 & 23.3 & 26.1 & 0.59 \\
Ile & $69.4^{\mathrm{a}}$ & $61.3^{\mathrm{b}}$ & $69.9^{\mathrm{a}}$ & $54.5^{\mathrm{b}}$ & $60.6^{\mathrm{b}}$ & 0.0004 \\
Thr & 78.4 & 75.1 & 79.7 & 73.8 & 75.6 & 0.07 \\
His & 22.1 & 23.7 & 24.4 & 25.9 & 25.8 & 0.11 \\
Leu & 119.9 & 113.8 & 118.4 & 111.0 & 110.7 & 0.04 \\
Val & 65.2 & 65.7 & 67.3 & 67.1 & 66.1 & 0.37 \\
Phe & $37.3^{\mathrm{c}}$ & $39.9^{\mathrm{bc}}$ & $41.6^{\text {ab }}$ & $43.8^{\mathrm{a}}$ & $43.8^{\mathrm{a}}$ & $<0.0001$ \\
Trp & 23.4 & 21.7 & 22.7 & 21.5 & 21.6 & 0.03 \\
Arg & $29.2^{\mathrm{c}}$ & $33.8^{\mathrm{b}}$ & $34.7^{\mathrm{b}}$ & $40.1^{\mathrm{a}}$ & $40.1^{\mathrm{a}}$ & $<0.0001$ \\
Cys & $24.4^{\mathrm{b}}$ & 25.6 & 26.6 & 26.4 & 26.5 & 0.81 \\
Tyr & $30.4^{\mathrm{c}}$ & $32.9^{\mathrm{b}}$ & $34.0^{\mathrm{b}}$ & $36.6^{\mathrm{a}}$ & $36.7^{\mathrm{a}}$ & $<0.0001$ \\
Met + Cys & $63.3^{\mathrm{c}}$ & 49.3 & 54.9 & 49.7 & 52.6 & 0.85 \\
Phe + Tyr & $67.7^{\mathrm{c}}$ & $72.9^{\mathrm{b}}$ & $75.6^{\mathrm{b}}$ & $80.5^{\mathrm{a}}$ & $80.5^{\mathrm{a}}$ & $<0.0001$ \\
\hline
\end{tabular}

${ }^{\mathrm{a}-\mathrm{c}}$ Means within a row with different superscripts differ $(P<0.05)$.

${ }^{1} \mathrm{M}=$ all-milk control; $5 \mathrm{P}=5 \% \mathrm{PP} ; 5 \mathrm{PA}=5 \% \mathrm{PP}$ with Ile and Thr to equal $\mathrm{M} ; 10 \mathrm{P}=10 \% \mathrm{PP} ; 10 \mathrm{PA}=10 \%$

$\mathrm{PP}$ with Ile and Thr to equal M. 
Table 5. Intakes of DM, CP, ME, and Lys of dairy calves fed experimental milk replacers containing plasma protein (PP) without or with supplemental Ile and Thr

\begin{tabular}{|c|c|c|c|c|c|c|c|c|c|}
\hline \multirow[b]{2}{*}{ Variable } & \multicolumn{5}{|c|}{ Treatment $(\text { Trt })^{1}$} & \multirow[b]{2}{*}{$\mathrm{SE}$} & \multicolumn{3}{|c|}{$P$-value } \\
\hline & M & $5 \mathrm{P}$ & $5 \mathrm{PA}$ & $10 \mathrm{P}$ & $10 \mathrm{PA}$ & & Trt & Time & Trt $\times$ time \\
\hline $\mathrm{DM}, \mathrm{g} / \mathrm{d}$ & 767 & 771 & 777 & 753 & 767 & 9.1 & 0.38 & $<0.0001$ & 0.64 \\
\hline $\mathrm{CP}, \mathrm{g} / \mathrm{d}$ & 174 & 175 & 178 & 172 & 175 & 2.1 & 0.38 & $<0.0001$ & 0.69 \\
\hline $\mathrm{ME}, \mathrm{kcal} / \mathrm{d}$ & 2,468 & 3,458 & 3,431 & 3,371 & 3,412 & 41 & 0.36 & $<0.0001$ & 0.63 \\
\hline $\mathrm{DM}, \mathrm{g} / \mathrm{d}$ & 897 & 912 & 906 & 863 & 913 & 15.8 & 0.08 & $<0.0001$ & 0.70 \\
\hline $\mathrm{CP}, \mathrm{g} / \mathrm{d}$ & 203 & 207 & 207 & 198 & 208 & 3.6 & 0.12 & $<0.0001$ & 0.76 \\
\hline $\mathrm{ME}, \mathrm{kcal} / \mathrm{d}$ & 4,054 & 4,093 & 4,000 & 3,863 & 4,058 & 71 & 0.09 & $<0.0001$ & 0.69 \\
\hline Lys, $\mathrm{g} / \mathrm{d}$ & $17.22^{\mathrm{b}}$ & $18.34^{\mathrm{a}}$ & $17.29^{\mathrm{b}}$ & $16.74^{\mathrm{b}}$ & $18.44^{\mathrm{a}}$ & 0.31 & $<0.0001$ & $<0.0001$ & 0.41 \\
\hline \multicolumn{10}{|l|}{ Starter, wk $6-8$} \\
\hline $\mathrm{DM}, \mathrm{g} / \mathrm{d}$ & 719 & 826 & 704 & 805 & 797 & 52.9 & 0.38 & $<0.0001$ & 0.93 \\
\hline $\mathrm{CP}, \mathrm{g} / \mathrm{d}$ & 171 & 196 & 167 & 192 & 190 & 12.6 & 0.38 & $<0.0001$ & 0.93 \\
\hline
\end{tabular}

${ }^{\mathrm{a}, \mathrm{b}}$ Means within a row with different superscripts differ $(P<0.05)$.

${ }^{1} \mathrm{M}=$ all-milk control; $5 \mathrm{P}=5 \% \mathrm{PP} ; 5 \mathrm{PA}=5 \% \mathrm{PP}$ with Ile and Thr to equal $\mathrm{M} ; 10 \mathrm{P}=10 \% \mathrm{PP} ; 10 \mathrm{PA}=10 \% \mathrm{PP}$ with Ile and Thr to equal M.

(g/d) during wk 1 to 5, with calves fed treatments $5 \mathrm{P}$ and 10PA consuming 15.5 and $15.5 \mathrm{~g} / \mathrm{d}$, while calves fed treatments M, 5PA, and 10P consumed 14.7, 14.8, and $14.6 \mathrm{~g} / \mathrm{d}$, respectively. A significant treatment difference also existed for Lys intake (from MR only) during wk 6 to 8 , with calves fed treatments $5 \mathrm{P}$ and 10PA consuming 18.3 and $18.4 \mathrm{~g} / \mathrm{d}$, while those fed treatments $\mathrm{M}, 5 \mathrm{PA}$, and $10 \mathrm{P}$ consumed 17.2, 17.3, and $16.7 \mathrm{~g} / \mathrm{d}$, respectively. These differences in Lys intake reflect small differences in DMI and analyzed Lys concentrations in the MR.

Overall intake of starter and total intake of MR plus starter for wk 6 to 8 are also shown in Table 5. No differences were found in intakes of DM, CP, or ME for starter and consequently for combined intakes of MR and starter during wk 6 to 8 .

Milk replacer intake for wk 1 to 8 is shown in Figure 1. No difference was found in MR intake $(\mathrm{g} / \mathrm{d})$ over the 8 wk; however, calves fed treatment $10 \mathrm{P}$ had numerically lower intakes than the other treatments in wk 6 and 7 . This finding corresponded to the trend detected in analysis of data from wk 6 to 8 as described earlier.

\section{Growth}

Mean BW, ADG, feed efficiency (gain:feed and gain:Lys), and growth measurements are presented in Table 6. Initial BW was not different among treatments $(P=0.97)$. Average environmental temperature for all 3 groups was below thermoneutral conditions for young calves under 3 wk of age (NRC, 2001). The ADG for the first $5 \mathrm{wk}$ of the study averaged $475 \mathrm{~g} / \mathrm{d}$, and expected energy allowable ADG under thermoneutral conditions was $560 \mathrm{~g} / \mathrm{d}$. Calculations from the NRC (2001) with the decreasing mean temperatures for each group showed decreasing energy allowable ADG, which likely was the cause of the ADG being less than expected energy allowable ADG. A significant treatment difference existed for gain:feed $(\mathrm{kg} / \mathrm{kg})$ with calves fed treatment 10P having the lowest efficiency $(0.54 \mathrm{~kg} /$ $\mathrm{kg}$ ), while treatments $\mathrm{M}, 5 \mathrm{P}, 5 \mathrm{PA}$, and 10PA achieved efficiencies of $0.61,0.65,0.62$, and $0.65 \mathrm{~kg} / \mathrm{kg}$, respectively. Treatment by time interactions were significant for heart girth and heart girth ADG, with calves fed treatment 10P having the lowest heart girth $(84.8 \mathrm{~cm})$ and lowest heart girth ADG $(0.24 \mathrm{~cm} / \mathrm{d})$ compared with the other treatments.

No difference was found among treatments in final BW at the end of wk $8(P=0.12)$, but the interaction of treatment by time was significant for BW (Figure 2). During wk 6 and 8, treatment 10P had the lowest BW compared with the other treatments, and in wk 7 treatment 10P had lower $\mathrm{BW}$ than treatments $5 \mathrm{P}$ and 10PA. The effect of treatment was significant for ADG with calves fed treatment $10 \mathrm{P}$ having the lowest gains $(670 \mathrm{~g} / \mathrm{d})$, while treatment $\mathrm{M}, 5 \mathrm{P}, 5 \mathrm{PA}$, and $10 \mathrm{PA}$ achieved $723,774,720$, and $752 \mathrm{~g} / \mathrm{d}$, respectively. A significant treatment difference existed for gain:feed $(\mathrm{kg} /$ $\mathrm{kg}$ ), with calves fed treatment $10 \mathrm{P}$ having the lowest efficiency $(0.58 \mathrm{~kg} / \mathrm{kg})$, while treatment $\mathrm{M}, 5 \mathrm{P}, 5 \mathrm{PA}$, 


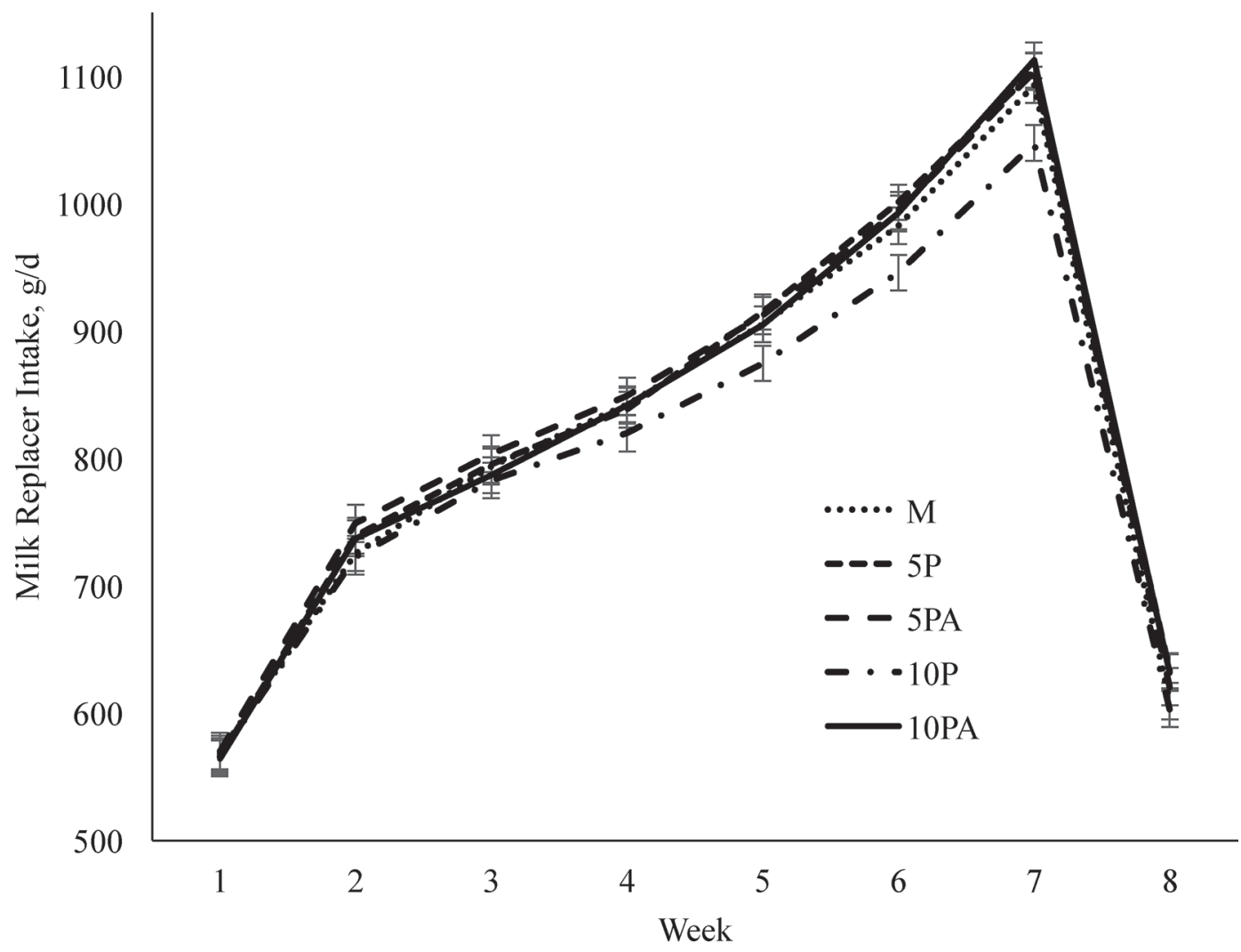

Figure 1. Milk replacer intake $(\mathrm{g} / \mathrm{d})$ by dairy calves fed experimental milk replacers containing plasma protein $(\mathrm{PP})$. The treatments were all-milk control (M), 5\% PP (5P), 5\% PP with Ile and Thr to equal M (5PA), 10\% PP (10P), and 10\% PP with Ile and Thr to equal M (10PA). Error bars represent SE of the least squares means.

and 10PA achieved efficiencies of $0.64,0.68,0.65$, and $0.67 \mathrm{~kg} / \mathrm{kg}$, respectively.

Withers height was not different among treatments. Heart girth and heart girth ADG both had significant treatment by time interactions. In wk 7 calves fed treatment $10 \mathrm{P}$ had the smallest heart girth compared with all other treatments (data not shown).

\section{Blood Metabolites}

Concentrations of total protein, urea $\mathrm{N}$, albumin, and total globulin are presented in Table 6. No difference was found among treatments $(P>0.10)$ for total protein or urea N. A significant difference existed among treatments for serum albumin concentrations, with treatment $5 \mathrm{P}$ having the highest $(2.88 \mathrm{~g} / \mathrm{dL})$ and all other treatments averaging $2.72 \mathrm{~g} / \mathrm{dL}$. A tendency $(P=$ 0.07 ) was noted for a treatment by time interaction for globulin. Treatment 5P had the lowest concentration of globulin $(2.26 \mathrm{~g} / \mathrm{dL})$, treatment 10PA had the highest $(2.46 \mathrm{~g} / \mathrm{dL})$, and the other treatments were intermediate; however, these differences were not significant $(P$ $>0.10)$.

\section{Health}

Data from 105 calves (21 calves per treatment) were obtained. One calf from treatment 5PA was not included in the final analysis because it was sick at arrival and did not recover. Overall, 2 calves from treatment $\mathrm{M}$ died, one of bloat on d 52 of the study and the second was euthanized on d 32 because of an abscess on the spine. One calf each from treatments 5PA, 10P, and 10PA died during the experiment. The calf on treatment 5PA died from bloat on d 12. The calf on treatment 10P was euthanized because of frostbite on $\mathrm{d}$ 46. The calf on treatment 10PA died from a clostridial infection on d 14.

Initial serum total protein did not differ $(P>0.10)$ among treatments. Average fecal score during the first $21 \mathrm{~d}$ did not differ among treatments. Additionally, the mean total amount of electrolytes administered per calf did not differ over the study. Although the repeated measures analysis of weekly electrolyte intake resulted in significant effects of treatment, time, and the treatment by time interaction (data not shown), the values were not normally distributed and thus this analysis must be viewed with caution. 
Table 6. Body weight, ADG, gain:feed, stature measurements, and blood metabolites (serum) of dairy calves fed experimental milk replacers containing plasma protein (PP) without or with supplemental Ile and Thr

\begin{tabular}{|c|c|c|c|c|c|c|c|c|c|}
\hline \multirow[b]{2}{*}{ Variable } & \multicolumn{5}{|c|}{ Treatment $(\text { Trt })^{1}$} & \multirow[b]{2}{*}{$\mathrm{SE}$} & \multicolumn{3}{|c|}{$P$-value } \\
\hline & M & $5 \mathrm{P}$ & $5 \mathrm{PA}$ & $10 \mathrm{P}$ & $10 \mathrm{PA}$ & & Trt & Time & Trt $\times$ time \\
\hline Final BW, kg & 58.6 & 59.6 & 58.8 & 56.0 & 59.3 & 1.7 & 0.17 & - & - \\
\hline Mean BW, kg & 50.7 & 51.1 & 51.0 & 49.5 & 50.8 & 0.69 & 0.45 & $<0.0001$ & 0.42 \\
\hline $\mathrm{ADG}, \mathrm{g} / \mathrm{d}$ & 479 & 503 & 484 & 411 & 497 & 32.38 & 0.12 & $<0.0001$ & 0.99 \\
\hline \multicolumn{10}{|l|}{ Wk $6-8$} \\
\hline $\mathrm{ADG}, \mathrm{g} / \mathrm{d}$ & 1,137 & 1,224 & 1,117 & 1,106 & 1,175 & 44 & 0.18 & $<0.0001$ & 0.71 \\
\hline Gain:feed, kg/kg & 0.69 & 0.74 & 0.70 & 0.66 & 0.70 & 0.3 & 0.52 & 0.58 & 0.54 \\
\hline \multicolumn{10}{|l|}{ Wk $1-8$} \\
\hline Final BW, kg & 82.8 & 85.3 & 82.3 & 79.7 & 83.9 & 2.1 & 0.12 & - & - \\
\hline Mean BW, kg & 59.4 & 60.2 & 59.6 & 57.6 & 59.9 & 0.86 & 0.15 & $<0.0001$ & 0.03 \\
\hline $\mathrm{ADG}, \mathrm{g} / \mathrm{d}$ & $723^{\mathrm{ab}}$ & $774^{\mathrm{a}}$ & $720^{\mathrm{ab}}$ & $670^{\mathrm{b}}$ & $752^{\mathrm{a}}$ & 27.5 & 0.05 & $<0.0001$ & 0.99 \\
\hline \multicolumn{10}{|l|}{ Serum metabolites } \\
\hline Total protein, g/dL & 5.13 & 5.15 & 5.09 & 5.12 & 5.18 & 0.09 & 0.96 & $<0.0001$ & 0.11 \\
\hline Urea $\mathrm{N}, \mathrm{mg} / \mathrm{dL}$ & 6.95 & 6.50 & 6.75 & 6.55 & 6.06 & 0.28 & 0.20 & 0.42 & 0.14 \\
\hline Albumin, $\mathrm{g} / \mathrm{dL}$ & $2.72^{\mathrm{b}}$ & $2.88^{\mathrm{a}}$ & $2.72^{\mathrm{b}}$ & $2.72^{\mathrm{b}}$ & $2.72^{\mathrm{b}}$ & 0.04 & 0.007 & $<0.0001$ & 0.59 \\
\hline Total globulin, g/dL & 2.41 & 2.26 & 2.37 & 2.40 & 2.46 & 0.08 & 0.51 & $<0.0001$ & 0.07 \\
\hline
\end{tabular}

${ }_{\mathrm{a}, \mathrm{b}}$ Means within a row with different superscripts differ $(P<0.05)$.

${ }^{1} \mathrm{M}=$ all-milk control; $5 \mathrm{P}=5 \% \mathrm{PP} ; 5 \mathrm{PA}=5 \% \mathrm{PP}$ with Ile and Thr to equal $\mathrm{M} ; 10 \mathrm{P}=10 \% \mathrm{PP} ; 10 \mathrm{PA}=10 \% \mathrm{PP}$ with Ile and Thr to equal M.

Table 7 shows the logistic models for the occurrence of scours (score $>2$ ) and medication with antibiotics. In the first $21 \mathrm{~d}$, scours occurrence was higher for calves fed treatment $\mathrm{M}$ than for those fed treatments $10 \mathrm{P}$ and $10 \mathrm{PA}(\mathrm{OR}=1.38, P=0.04$ and $\mathrm{OR}=1.62, P=0.004$, respectively), and scours occurrence for treatment $5 \mathrm{PA}$ tended to be higher than for treatment 10PA $(\mathrm{OR}=$ $1.18, P=0.09)$. The chance of antibiotic treatment was greater in treatment $\mathrm{M}$ than in treatments $5 \mathrm{P}, 5 \mathrm{PA}$, and $10 \mathrm{PA}(\mathrm{OR}=2.60, P=0.0003 ; \mathrm{OR}=3.41, P<$ $0.0001 ; \mathrm{OR}=2.47, P=0.0004)$, greater for treatment $10 \mathrm{P}$ than treatment $10 \mathrm{PA}(\mathrm{OR}=2.04, P=0.007)$, and lower in treatments $5 \mathrm{P}$ and $5 \mathrm{PA}$ than treatment $10 \mathrm{P}$ $(\mathrm{OR}=0.46, P=0.005 ; 0.35, P=0.0007)$.

Table 8 shows the logistic models for the number of days with scours and the duration of treatment with antibiotics. All treatments were compared to the control (M). Compared with treatment $\mathrm{M}$ calves, those fed treatments 10P and 10PA had fewer days of scours (2.69 d, $P=0.06$ and $2.21 \mathrm{~d}, P=0.005$, respectively). Calves in treatments 5P, 5PA, and 10PA had fewer days of treatment with antibiotics compared to calves in treatment $\mathrm{M}(0.9 \mathrm{~d}, P=0.003 ; 0.7 \mathrm{~d}, P<0.001$; and $0.95 \mathrm{~d}, P=0.0005$, respectively). Contrast statements also were used to compare treatment means (Table 8). For days with scours, the contrast of the linear effect of increasing PP without supplemental AA (treatments $\mathrm{M}, 5 \mathrm{P}$, and $10 \mathrm{P})$ approached significance $(P=0.06)$ and the linear effect of increasing $\mathrm{PP}$ with supplemental AA (treatments M, 5PA, and 10PA) was significant. For days medicated, the contrast comparing plasmasupplemented diets without and with supplemental AA (treatments $5 \mathrm{P}$ and $10 \mathrm{P}$ vs. treatments $5 \mathrm{PA}$ and $10 \mathrm{PA}$ ) was significant, as was the linear effect of increasing PP with supplemental AA (treatments $\mathrm{M}$, 5PA, and 10PA).

\section{DISCUSSION}

The goal of the current trial was to evaluate the response to PP inclusion rates of 5 or $10 \%$ (18 and $36 \%$ of dietary $\mathrm{CP}$, respectively) of the formulation either without or with supplementation of Ile and Thr. Several previous studies have evaluated lower levels $(<25 \%$ of dietary $\mathrm{CP}$ ) of inclusion of PP into calf MR fed in more restricted amounts than the current study. Morrill et al. (1995) reported an advantage in BW gains for calves fed a MR containing PP (25\% of dietary CP) versus a MR containing all-milk proteins. Quigley and Bernard (1996) observed similar growth performance in calves fed MR with PP (25\% of dietary CP) compared to calves fed MR with all-milk proteins. Vasquez et 


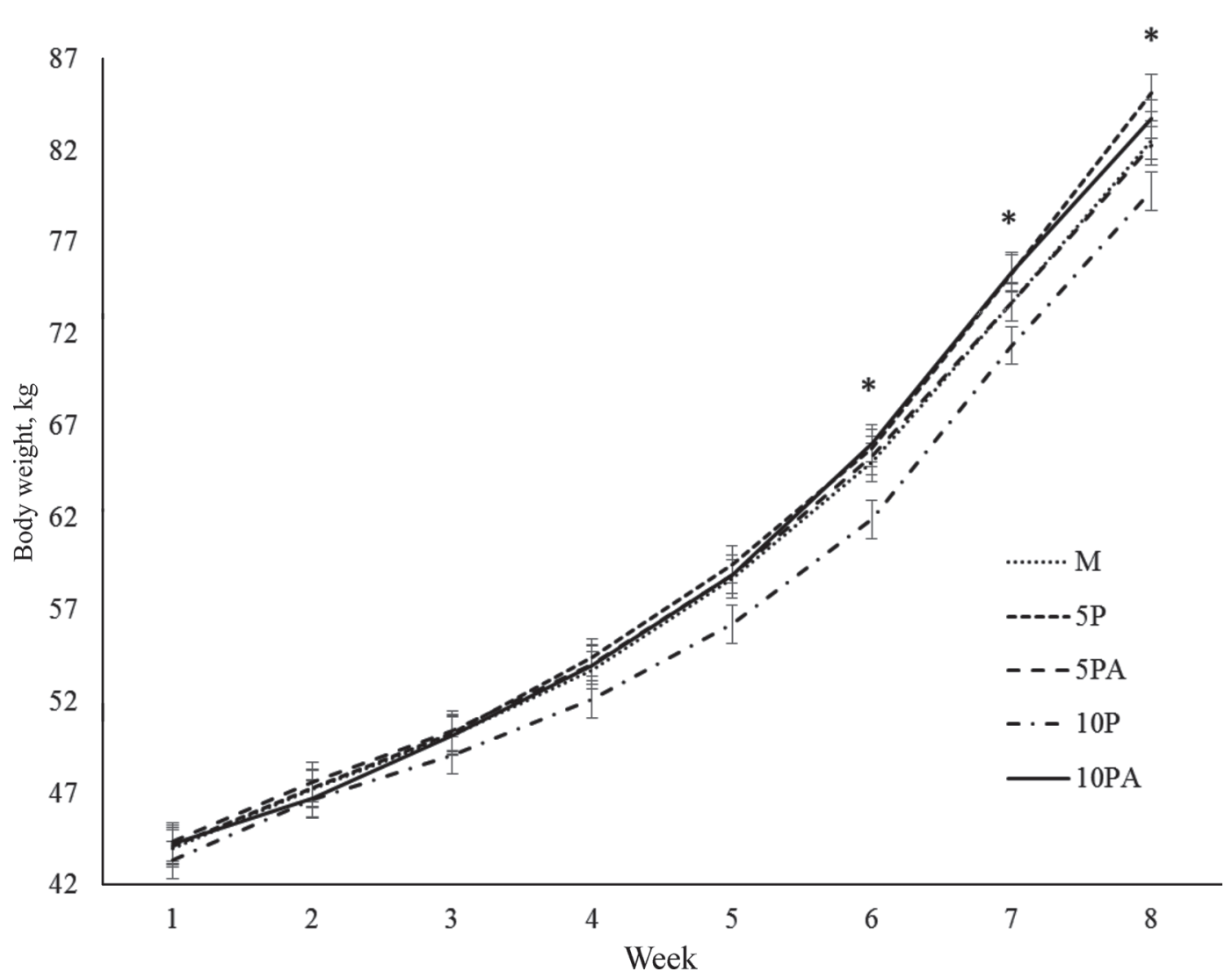

Figure 2. Body weight $(\mathrm{kg})$ of dairy calves fed experimental milk replacers containing plasma protein $(\mathrm{PP})$ without or with supplemental Ile and Thr $\left({ }^{*} \mathrm{P} \leq 0.05\right)$. The treatments were all-milk control $(\mathrm{M}), 5 \% \mathrm{PP}(5 \mathrm{P}), 5 \% \mathrm{PP}$ with Ile and Thr to equal M (5PA), $10 \% \mathrm{PP}(10 \mathrm{P})$, and $10 \%$ PP with Ile and Thr to equal M (10PA). Error bars represent SE of the least squares means.

al. (2017) investigated the response of higher inclusion $(>33 \%$ of the dietary $\mathrm{CP})$ of PP in calf MR; as inclusion increased over $33 \%$, growth rates and efficiency were decreased. Vasquez et al. (2017) tested the effect of supplementing MR containing increasing amounts of $\mathrm{PP}$ with Ile to match the AA profile of the control all-

Table 7. Logistic model for scours and medication occurrence by comparison of experimental milk replacers containing plasma protein (PP) fed to dairy calves

\begin{tabular}{lrcccc}
\hline Variable and comparison $^{1}$ & Coefficient & SEM & Odds ratio $^{2}$ & 95\% CI & $P$-value \\
\hline Scours occurrence $^{3}$ (d 1-21) & & & & & \\
M, 10P & 0.3207 & 0.1566 & 1.38 & $1.01,1.88$ & 0.04 \\
M, 10PA & 0.4849 & 0.1680 & 1.62 & $1.17,2.25$ & 0.004 \\
5PA, 10PA & 0.3054 & 0.1787 & 1.18 & $0.95,1.93$ & 0.09 \\
Medicated & (all weeks) & & & & \\
M, 5P & 0.9559 & 0.2624 & 2.60 & $1.55,4.35$ & 0.0003 \\
M, 5PA & 1.2264 & 0.2992 & 3.41 & $1.90,6.11$ & $<0.0001$ \\
M, 10PA & 0.9046 & 0.2574 & 2.47 & $1.49,4.09$ & 0.0004 \\
5P, 10P & -0.7666 & 0.2702 & 0.46 & $0.27,0.79$ & 0.005 \\
5PA, 10P & -1.0371 & 0.3062 & 0.35 & $0.19,0.64$ & 0.0007 \\
10P, 10PA & 0.7153 & 0.2654 & 2.04 & $1.22,3.46$ & 0.007
\end{tabular}

${ }^{1} \mathrm{M}=$ all-milk control; $5 \mathrm{P}=5 \% \mathrm{PP} ; 5 \mathrm{PA}=5 \% \mathrm{PP}$ with Ile and Thr to equal $\mathrm{M} ; 10 \mathrm{P}=10 \% \mathrm{PP} ; 10 \mathrm{PA}=10 \%$ $\mathrm{PP}$ with Ile and Thr to equal M.

${ }^{2}$ The odds ratio (OR) indicates the probability of either having scours or needing medication for the first milk replacer (MR) diet in comparison to the second MR diet. If the OR is $>1$, the first MR diet in the comparison is more likely to have scours or to be medicated than the second MR diet by a factor of the difference above 1 . If the $\mathrm{OR}$ is $<1$, the first MR diet has a lower probability of occurrence than the second MR diet.

${ }^{3}$ All other comparisons were not significant $(P>0.10)$. 
milk protein MR; they found that Ile supplementation lessened but did not overcome the decreased performance as PP inclusion increased over $33 \%$. The results of that study indicated that Thr might have become limiting at higher inclusion rates of PP.

In the current study, ADG and gain:feed decreased for calves fed the higher inclusion of PP without supplementation of AA. These results reflect similar observations by Morrill et al. (1995) and Vasquez et al. (2017), whereas Quigley and Bernard (1996) found no difference between milk proteins and PP. The limitations at the higher PP inclusion were overcome when AA were supplemented (Table 6). Intakes of DM, CP, and ME were not different among treatments, but gain:feed was lower for calves fed the higher plasma inclusion without AA (10P; Table 6). The lower ADG and efficiency were not reflected in body stature measurements except heart girth during wk 7 when calves fed 10P had the lowest heart girth compared with the other treatments (Table 6). Our results indicate that bovine PP supported growth equivalent to whey proteins when the EAA profile was maintained similar to that of whey proteins.

To be able to detect limitations in growth caused by differences in protein digestibility or AA profile among treatments, we aimed to have protein-allowable ADG lower than energy-allowable ADG as calculated using NRC (2001) equations. The environmental temperatures experienced in this study were below the thermoneutral range, and consequently the calculated energy-allowable ADG were equivalent to or less than protein-allowable ADG. Although energy was likely more limiting during the most extreme temperatures, we believe that protein continued to be the most limiting overall and that relative treatment responses were valid. Hutches were placed to limit exposure to prevailing winds and to receive direct sunlight all day, and they were kept well bedded with straw. These factors should have moderated hutch temperatures (not measured) and ambient temperature of the calves when lying in the straw bedding. Thus, the effective environmental temperature likely was considerably warmer than weather station reported temperatures, which would decrease the calves' actual maintenance requirement in comparison with requirements predicted from outdoor temperatures. In addition, the lower critical temperature of calves decreases over the first $3 \mathrm{wk}$ of life (NRC, 2001) as calves become more cold tolerant. Nevertheless, differences among treatments might have been more pronounced if calves were in a thermoneutral environment or if MR feeding rate was greater.

The serum concentration of albumin, although low, was within the normal range, but globulin levels for all treatments were below the normal range (Table 6) according to the Kahn (2010). The observed values for calves fed treatment $5 \mathrm{P}$ indicated that serum albumin concentration was higher compared with the other treatments. Albumin is influential in oncotic pressure and low values allow fluid to move from the vascular space. With low albumin concentration and low oncotic pressure, transport of substances, including hormones and electrolytes, in plasma is reduced (Radostits and

Table 8. Poisson regression for days with scours and days medicated by comparison of experimental milk replacers containing plasma protein (PP) fed to dairy calves

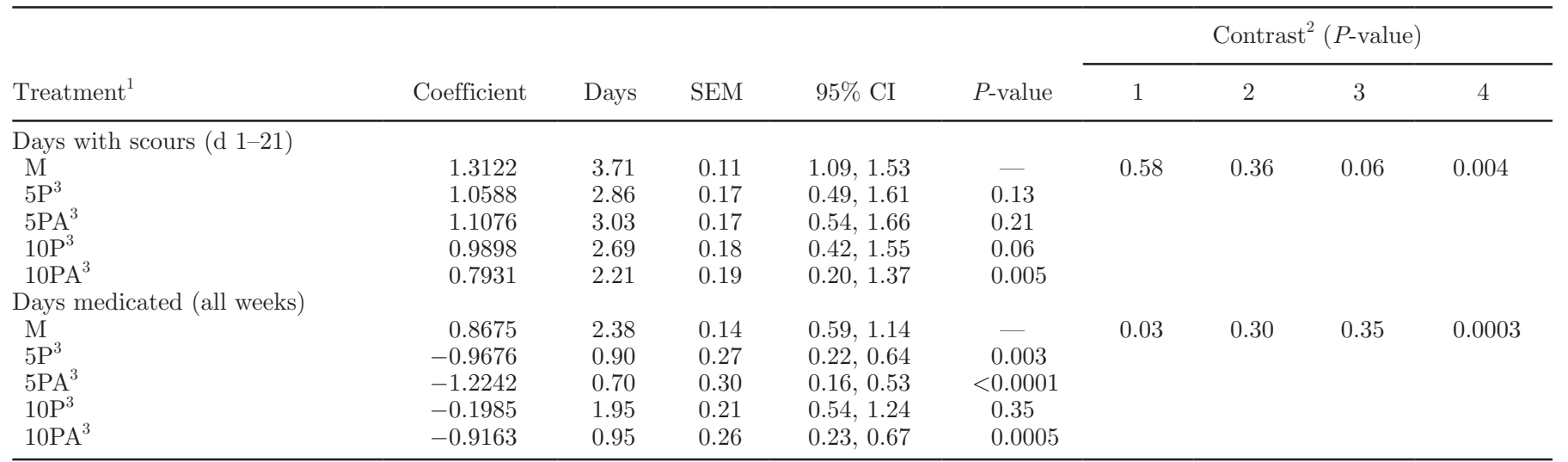

${ }^{1} \mathrm{M}=$ all-milk control; $5 \mathrm{P}=5 \% \mathrm{PP}$ (plasma protein); $5 \mathrm{PA}=5 \% \mathrm{PP}$ with Ile and Thr to equal $\mathrm{M} ; 10 \mathrm{P}=10 \% \mathrm{PP} ; 10 \mathrm{PA}=10 \% \mathrm{PP}$ with Ile and Thr to equal M.

${ }^{2}$ Contrast statements: $1=\mathrm{AA}$ effect (treatment $5 \mathrm{P}$ and $10 \mathrm{P}$ vs. treatment $5 \mathrm{PA}$ and $\left.10 \mathrm{PA}\right) ; 2=$ interaction of plasma level and AA; (treatment $5 \mathrm{P}$ and $5 \mathrm{PA}$ vs. treatment $10 \mathrm{P}$ and $10 \mathrm{PA}$ ); $3=$ linear plasma level without AA (treatment $\mathrm{M}, 5 \mathrm{P}$, and $10 \mathrm{P}$ ); $4=$ linear plasma level with AA (treatment $\mathrm{M}, 5 \mathrm{PA}$, and 10PA).

${ }^{3}$ All treatments compared with M (control). 
Done, 2007). The globulin fraction is composed of enzymes, carrier proteins, and immunoglobulins. The concentrations in blood are indicative of immune system activity, and higher concentrations may indicate an immune response (Keraan et al., 1974).

Considerable interest exists in the potential for spray-dried PP as an opportunity to improve the health of calves. In the swine industry, PP are widely used in the diets of weanling piglets to improve feed intake and decrease postweaning diarrhea (Torrallardona, 2010). Quigley et al. (2002) investigated the use of PP in MR for young calves. They found that calves fed MR with PP $(16 \%$ of dietary CP) tended $(P<0.10)$ to have lower fecal scores and lower use of antibiotics than the all-milk control. Quigley and Wolfe (2003) also reported that calves fed MR containing PP (20\% of dietary $\mathrm{CP}$ ) had fewer days with scours (fecal score $>2$ ) than calves fed the all-milk control. They did not, however, observe a reduction in the use of medications compared to the control. Similar results were observed in our study. During the first $3 \mathrm{wk}$, calves fed the all-milk control had a greater probability for occurrence of scours (Table 7) and to have scours for a longer duration than calves fed diets containing the higher inclusion of PP (Table 8). Calves fed the all-milk control or the higher level of PP without AA supplementation (10P) had a higher probability of being medicated (Table 7) and to be medicated for a longer duration (Table 8) than calves fed the other MR containing PP. These results indicate that bovine PP may have beneficial effects on gut health during early life in calves, but the AA profile must be balanced for this beneficial effect to be maximized. Although not specifically investigated in this study, intestinal mucins are enriched in Thr, and limited dietary $\mathrm{Thr}$ in rats decreased intestinal mucin synthesis (Faure et al., 2005). Furthermore, diets deficient in Thr fed to piglets increased susceptibility to diarrhea (Law et al., 2007). Whether these factors influenced gut health in our study when Thr might have been limiting $(10 \mathrm{P})$ is not clear.

Diets containing PP (with its immunoglobulin and albumin components) maintained performance in piglets similar to diets formulated with isolated plasma fractions of either IgG or albumin, and diets containing $\mathrm{PP}$ or its fractions improved performance relative to negative controls without PP or its components (Owen et al., 1995). The immunoglobulins provided in PP have a protective effect against the adhesion of some pathogens and so prevent colonization of the enterocytes in the intestine (Bosi et al., 2001); this possible local protection by the immunoglobulin fraction may explain the improved performance and shorter duration of health incidences for calves fed PP compared with the control.

\section{CONCLUSIONS}

Results from previous research indicated that Thr may have become limiting when PP was included at more than $33 \%$ of dietary CP. Results of the current study indicate that with supplementation of Ile and Thr, growth of calves fed a MR containing PP to replace $36 \%$ of the dietary CP was not different from that of calves fed MR with a lower plasma inclusion rate or an all-milk protein MR. Results indicate that spraydried bovine PP in MR decreased the occurrence and duration of scours in young calves compared with the all-milk control. Health benefits were greater when Ile and Thr were supplemented to the higher PP inclusion rate. Overall, results of this study indicate that PP supports growth performance similar to an all-milk protein control MR, and inclusion of PP improved health as long as formulations were balanced for Ile and Thr in addition to Met and Lys.

\section{ACKNOWLEDGMENTS}

This project was supported by state and federal funds appropriated to the Illinois Agricultural Experiment Station and by APC Inc. (Ankeny, IA). The authors extend appreciation to Milk Specialties Global (Eden Prairie, MN) for manufacture of the milk replacers and Land O'Lakes (St. Paul, MN) for donation of the electrolytes.

\section{REFERENCES}

Almeida, F. N., J. K. Htoo, J. Thomson, and H. H. Stein. 2013. Comparative amino acid digestibility in US blood products fed to weanling pigs. Anim. Feed Sci. Technol. 181:80-86.

Bosi, P., In K. Han, H. J. Jung, K. N. Heo, S. Perini, A. M. Castellazzi, L. Casini, D. Creston, and C. Gremokolini. 2001. Effect of different spray dried plasmas on growth, ileal digestibility, nutrient deposition, immunity and health of early-weaned pigs challenged with $E$. coli K88. Asian-australas. J. Anim. Sci. 14:1138-1143.

Castro, J. J., G. H. Hwang, A. Saito, D. A. Vermeire, and J. K. Drackley. 2016. Assessment of the effect of methionine supplementation and inclusion of hydrolyzed wheat protein in milk protein based milk replacers on the performance of intensively fed Holstein calves. J. Dairy Sci. 99:6324-6333.

Davis, C. L., and J. K. Drackley. 1998. The Development, Nutrition, and Management of the Young Calf. Iowa State University Press, Ames.

Faure, M., D. Moënnoz, F. Montigon, C. Mettraux, D. Breuillé, and O. Ballèvre. 2005. Dietary threonine restriction specifically reduces intestinal mucin synthesis in rats. J. Nutr. 135:486-491.

Kahn, C. M., ed. 2005. The Merck Veterinary Manual. 9th ed. Merck and Co., New York, NY.

Keraan, M., O. L. Meyers, G. H. C. Engelbrecht, R. Hickman, S. J. Saunders, and J. Terblanche. 1974. Increased serum immunoglobulin levels following portacaval shunt in the normal rat. Gut 15:468-472.

Law, G. K., R. F. Bertolo, A. Adjiri-Awere, P. B. Pencharz, and R. O. Ball. 2007. Adequate oral threonine is critical for mucin production and gut function in neonatal piglets. Am. J. Physiol. Gastrointest. Liver Physiol. 292:G1293-G1301. 
Morrill, J. L., J. M. Morrill, and A. M. Feyerherm. 1995. Plasma proteins and a probiotic as ingredients in milk replacer. J. Dairy Sci. 78:902-907.

NAHMS (National Animal Health Monitoring System). 2011. Dairy, 2011, Part I: Reference of Dairy Cattle Health and Management Practices in the United States, 2011. Pub. N480.1007. US Department of Agriculture: Animal and Plant Health Inspection Service: Veterinary Services (USDA:APHIS:VS), Centers for Epidemiology and Animal Health (CEAH), Fort Collins, CO.

NRC. 2001. Nutrient requirements of the young calf. Pages 214-233 in Nutrient Requirements of Dairy Cattle. 7th rev. ed. Natl. Acad. Press, Washington, DC.

Owen, K. Q., J. L. Nelssen, R. D. Goodband, M. D. Tokach, K. G. Friesen, B. T. Richert II, J. W. Smith, and L. E. Russell. 1995. Effects of various fractions of spray dried plasma protein on performance of early-weaned pigs. The 1995 Swine Industry Day Report of Progress. Kansas State University, Manhattan.

Quigley, J. D., III, and J. K. Bernard. 1996. Milk replacers with or without animal plasma for dairy calves. J. Dairy Sci. 79:1881-1884.
Quigley, J. D., III, C. J. Kost, and T. A. Wolfe. 2002. Effects of spraydried animal plasma in milk replacers or additives containing serum and oligosaccharides on growth and health of calves. J. Dairy Sci. 85:413-421.

Quigley, J. D., III, and T. M. Wolfe. 2003. Effects of spray dried animal plasma in calf milk replacer on health and growth of dairy calves. J. Dairy Sci. 86:586-592.

Radostits, O. M., and S. H. Done. 2007. Veterinary Medicine: A Textbook of the Diseases of Cattle, Sheep, Pigs, Goats, and Horses. Elsevier Saunders, Philadelphia, PA

Torrallardona, D. 2010. Spray dried animal plasma as an alternative to antibiotics in weanling pigs. A review. Asian-Australas. J. Anim. Sci. 23:131-148

Vasquez, K. M., S. Y. Morrison, J. M. Campbell, and J. K. Drackley. 2017. Plasma protein and supplemental isoleucine in milk replacers for dairy calves. J. Dairy Sci. 100:293-304. 